\title{
Estimating cost of in-patient medical care for stroke using Casemix data
}

\author{
Nor Azlin Mohd Nordin ${ }^{1 *}$, Amrizal Muhamad Nur ${ }^{1}$, Saperi Sulong ${ }^{2}$, Syed Aljunid ${ }^{1,2}$ \\ From The 6th International Casemix Conference 2012 (6ICMC2012) \\ Kuala Lumpur, Malaysia. 6-7 June 2012
}

\section{Background}

There is a lack of data on financial impact of stroke despite the increase in hospital admissions due to this disease in Malaysia. This study aimed to estimate the cost of medical care for patients hospitalised in a main teaching hospital following a stroke.

\section{Method}

A retrospective analysis was conducted using data of stroke patients maintained by the Casemix Unit of Universiti Kebangsaan Malaysia Medical Centre. Variables studied were the patients' demography, clinical profiles and length of hospital stay. Cost evaluation was carried out from the hospital perspective using Top-down costing approach. Data was analysed with the use of SPSS version 19.

\section{Results}

Data of 748 stroke patients were retrieved for analysis. The average length of hospital stay was 6.4 (SD: 3.1) days. The mean cost of medical care was RM 3696.40 (SD: 1842.10) per stroke patient per admission. Human resources made up the highest cost component (RM 1343.90, SD: 669.8 ) or $36 \%$ of the total cost of care, followed by medications (RM 867.30, SD: 432.40) and laboratory tests (RM 337.90, SD: 168.40). The cost increased by $15 \%$ when patient suffered from moderately severe stroke and further increased by $52 \%$ in the highest level of severity compared to mild stroke $(\mathrm{p}<0.05)$. No significant differences were found when comparing costs between the sub-groups of age, gender and stroke sub-types.

\footnotetext{
* Correspondence: azlin8@yahoo.com

'United Nations University International Institute for Global Health, Kuala Lumpur, Malaysia
}

Full list of author information is available at the end of the article

\section{Conclusion}

There is a substantial cost involved in the care of inpatient stroke in this study. Further research involving other health care settings are required to better estimate the financial impact of stroke to this country.

\section{Author details}

'United Nations University International Institute for Global Health, Kuala Lumpur, Malaysia. ${ }^{2}$ International Casemix \& Clinical Coding Centre, Universiti Kebangsaan Malaysia, Kuala Lumpur, Malaysia.

Published: 21 November 2012

doi:10.1186/1472-6963-12-S1-P10

Cite this article as: Mohd Nordin et al:: Estimating cost of in-patient medical care for stroke using Casemix data. BMC Health Services Research 2012 12(Suppl 1):P10.
Submit your next manuscript to BioMed Central and take full advantage of:

- Convenient online submission

- Thorough peer review

- No space constraints or color figure charges

- Immediate publication on acceptance

- Inclusion in PubMed, CAS, Scopus and Google Scholar

- Research which is freely available for redistribution
() Biomed Central

\section{() Biomed Central}

